\title{
Human - river relations at various stages of development of water front factory settlements in Łódź
}

\author{
Elżbieta Szkurłat
}

Faculty of Geographical Sciences, University of Łódź, Kopcińskiego Str. 31, 90-142 Łódź, Poland, E-mail address: ela.szkurlat@gmail.com

\begin{abstract}
The purpose of this article is to analyze and clarify the circumstances which led to the current condition and degradation of the watercourses and rivers of Łódź. These rivers were the decisive factor in initiating and stimulating the industrial development of the city. A detailed analysis examined changes in the management of river waters in the vicinity of the socalled water-front factory settlements (referred to locally as "posiadła") in the River Jasien valley. This was the location of one of the first industrial settlements within the city of Łódź and took place shortly after the city was included by the Polish Kingdom authorities (in 1821) in the group of so-called factory cities intended for the development of the textile industry initially with emphasis on the cloth and linen making industry, with further transformation into the cotton industry. The article presents the forms and methods of use of the River Jasien in the period from the beginning of the 19th century up to the present. The specification assumed therefore the period of agricultural usage in the form of water mills, through textile manufacture, industrial production and the period after the fall of the textile industry. The River Jasien is an outstanding example of the way, in which people have "treated" the river during the successive stages of technological development of textile production. How close to the river they settled at the early stages of industrial development, slowly "moving away" from the river, leading to its gradual degradation, and abandoning it, restraining it to a covered channel, to ultimately forgetting it ever existed. The changes in these man - river relationships, as described in this document, can lead to conclusions for the future direction for the current spatial policy of the city. Also about these riverside post-industrial areas, with regard to the need to restore their original values and the need to protect and conserve their unique natural character and cultural heritage.
\end{abstract}

KEY WORDS: man - river relations, development, textile industry, river values

\section{Introduction}

Numerous river valleys constitute an intrinsic part of the natural and cultural landscape of Łódź, and are an important witness to the history of the city. They should therefore constitute an essential element of the quality of the urban space and, the city's identity and be the object of utmost care of the residents (and managers of the city), striving to preserve their timeless values. Unfortunately, the rivers of Łódź that once played a crucial role in the creation and initial industrial development of the city, are now on the margins of the city's spatial planning approach, and have a low presence in the memory and awareness of the residents. The literature devoted to these man river relationships includes a metaphor describing this situation as: the city that turned its back to the river (WIERZBICKA, 1996; PANCEWICZ, 2002; ANGIEL, 2011). Looking at the current condition of the rivers of Łódź, it is without a doubt that the city has in fact turned its back to the river. The main aim of this article is to discuss the circumstances and causes for shaping such negative man - river relationships in the Łódź city space. A detailed analysis will be performed for changes in the utilization of the river in the area of the waterfront factory settlements in the River Jasien valley. This valley is a unique place, a model depiction of the human standpoint on the river at various stages of technological development in a period of the rapid advancement of the textile industry of the $19^{\text {th }}$ and $20^{\text {th }}$ century. It is a clear depiction of how people have treated the river during the 
successive stages of technological development of the textile industry - how close to the river they settled at the early stages of industrial development, slowly "moving away" from the river, leading to its gradual degradation, to abandoning it, and restraining it to a covered channel.

The basis for the research was an analysis of documents and historical materials, including cartographic and photographic documentation, scientific studies devoted to the development of the textile industry in Łódź and from field observations.

\section{Physical and geographic specification of the area}

Similarly to the entire Central Poland region, one of the characteristic features of the city of Łódź is its location in the transitional zone between the North European Plain and the Polish Highlands (KONDRACKI, 1998). One of the determining features of the geological structure of the deep substratum is the channeled distribution of Cretaceous limestone and marls in the form of the so-called Łódź Basin which constitutes a vast sub-artesian water reservoir. The land form in the Łódź area is the result of continental glacier activity, and particularly the glacier waters and periglacial processes. The thickness of glacial sediments reaches approximately $150 \mathrm{~m}$ in the city area. These include primarily fluvioglacial sand, glacial till, as well as sands and gravels. A thick layer of loose postglacial sediments, particularly in the Łódź Heights area determined the natural, high abundance of groundwater sources and the formation of a dense river network. Within the city limits, there are considerable land inclinations resulting from the occurrence of terminal moraine elevations, plane areas and short valleys. The smallest differences in altitude can be found in the southwestern part of the city - in the River Ner valley. The largest inclinations occur in the northeastern part of the city (Fig. 1).

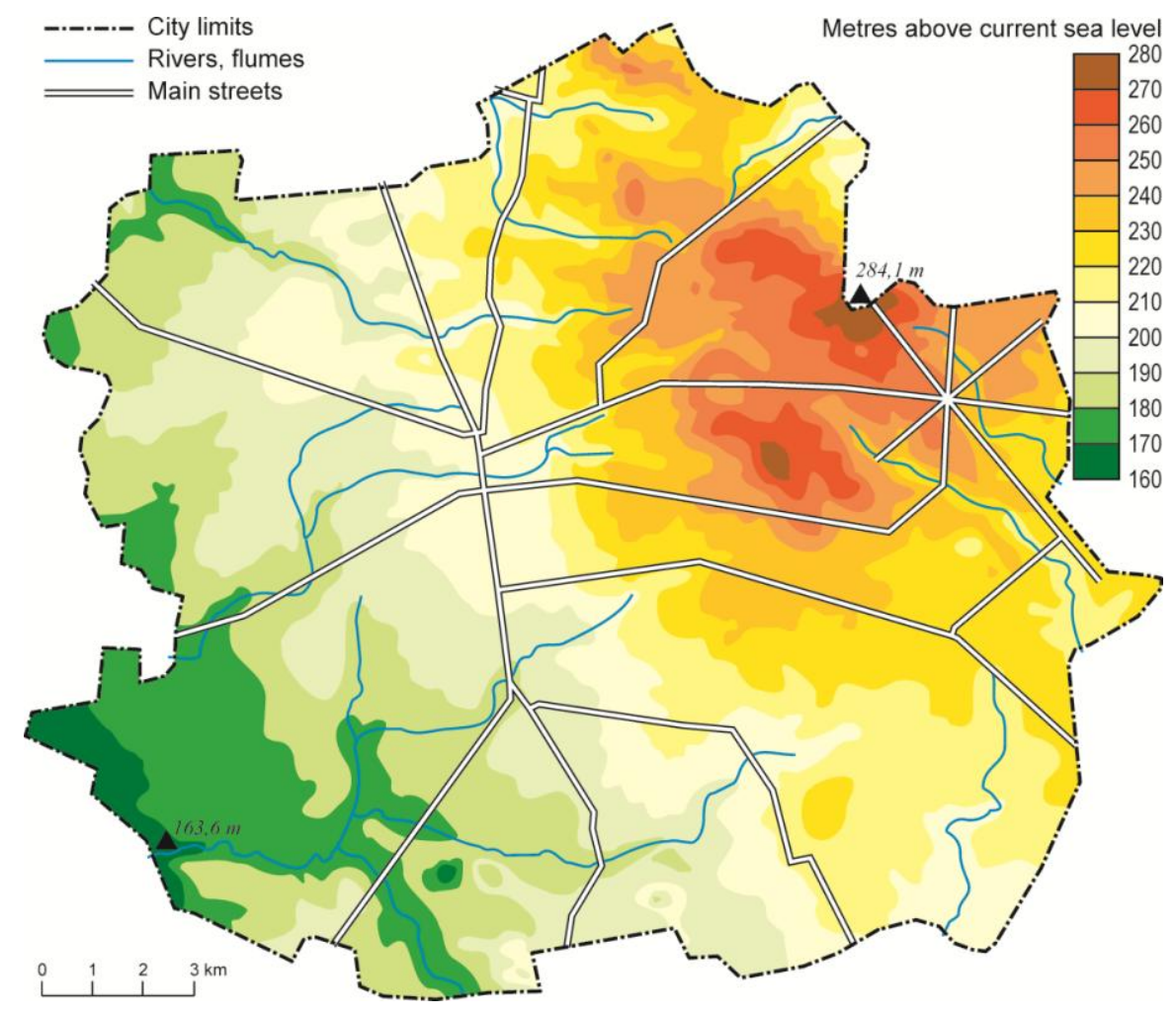

Fig. 1. Łódź - the height above sea level (source: Szkurłat, 2004)

There are no major river valleys in the Łódź area. In turn, there are numerous small valleys, whose initial sections are focused around the tallest elevations. Their tops are situated on the line of the $1^{\text {st }}$ row water divide separating the Vistula and Odra river basins. The River Ner and its tributaries: Olechówka, Jasień with Karolewka, Łódka with Bałutka, Jasieniec and Lubczyna originate on the western side of the water divide (its upper section flows through the southeastern part of Łódź). The northern part of the water divide is where the River Bzura originates along with its tributaries: Łagiewniczanka, Sokołówka with Brzoza and Moszczenica. The Miazga, a tributary to the River Pilica has its source on the eastern side of the divide (Fig. 2). 


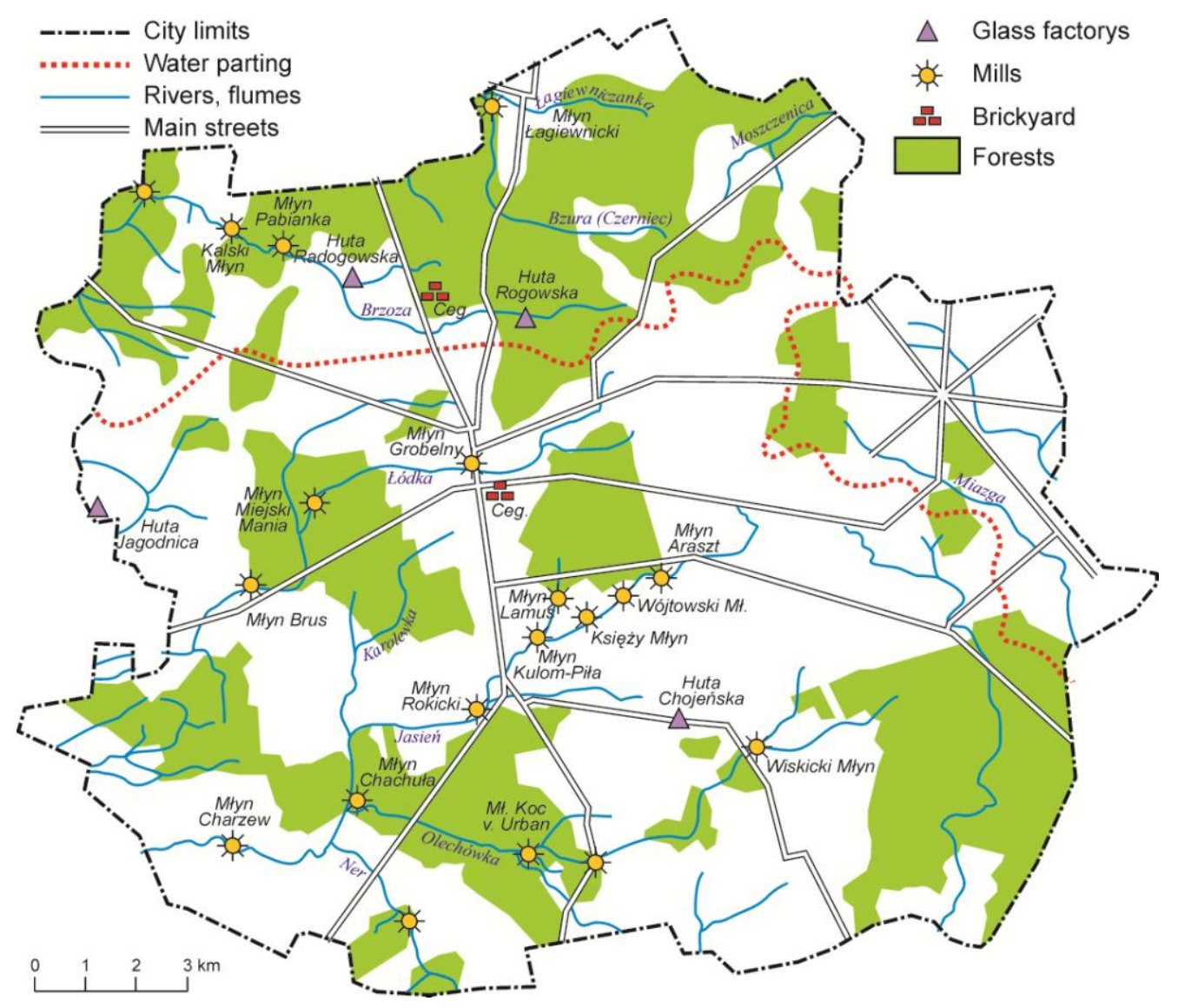

Fig. 2. River network in the Łódź area at the beginning of the $19^{\text {th }}$ century, showing the glassworks and brickyards (source: Szkurłat, 2004)

In the first half of the $19^{\text {th }}$ century, Łódź had abundant sources of surface waters. The marshy and woody character of the Łódź area was depicted by Oskar Flatt in his landscape description of Łódź from 1853 (FLATT, 1853). The abundance of waters in the $19^{\text {th }}$ century was shown by the number of water mills in the city. Currently, there are few places in Łódź, where surface waters can be observed; there is no trace of smaller streams. Many of them were buried. The beds of numerous rivers were covered with concrete or built over. Many of them were filled in. Their previous existence is proven solely by such local names as Kały (old Polish "Marshes"), Źródliska ("Sources"), Wodny Rynek (Water Square).

\section{The transformation of man - river relationships at various stages of development of water front factory settlements in the River Jasień valley in Łódź}

The location of Łódź in the water division zone constituted a barrier to settlement which resulted in the area of the current city, it was overgrown with a thick forest, it was inhabited very late and to only to a small extent (DYLIK, 1971; KOTER, 1974; LISZEWSKI, 2009). The oldest developments were created in the northern part of the current region in the $16^{\text {th }}-17^{\text {th }}$ centuries. These were the following estates: Kały, Radogoszcz, Łagiewniki and Modrzew. A low and very dispersed population was a consequence of the very wooded area in the $18^{\text {th }}$ century, when, according to calculations performed by Koter, forests covered c.a. $75 \%$ of the area of the current city (KoTER, 1973, 1974).

For centuries, the River Jasien was one of the primary sources of potable water and fish for the few residents and their farm animals, as well as wild animals. It was only in the $14^{\text {th }}$ century that the development of commercial handicraft settlements nearby caused an increase in the demand for crops, which stimulated growth in agricultural production, and hence the use of the abundant water in the River Jasien and its significant inclination for the purposes of numerous water mills. In the beginning of the $19^{\text {th }}$ century, there were 5 water mills in the central four kilometers section of the River Jasien (KoTER, 1969).

A turning point in the history of Łódź, and in the history of the River Jasień basin areas, was the inclusion in 1821 of the group of factories in the city intended as the textile industrial center, primarily for the production of wool and linen, and later - for the cotton industry (OSTROWSKI, 
1949; Koter, 1973; PUŚ, 1976; PUŚ \& PyTlas, 1979; BERBELSKA ET. AL., 1998; LISZEWSKI, 2009). Particular merit for the establishment of the Łódź textile center is attributed to Rajmund Rembieliński - the President of the Mazovian Voivodeship Commission, the body that initiated the inclusion of Łódź in the group of cities intended as future industrial centers by the of the Polish Kingdom for. The decisive factor was the presence of areas constituting state properties, their location on the "factory route", as well as the natural values of the city of Łódź. The abundant waters of the local rivers and streams proved particularly useful. The energy produced by falling water was used to power factory devices. The river also played another, important role in the textile industry: large volumes of clean water were used in the process of fabric whitewashing, rinsing, softening and dying (KoTER, 1973). It was Rajmund Rembieliński who, in 1821, wrote about the excellent topography of Łódź, and four years later, Stanisław Staszic confirmed these words in his renowned report from a round of the local industrial sites in the Kingdom, emphasizing the richness of waters in Łódź, required for the newly established textile industry:

"Łódź - a small, wooden government town, destined to house various factories for two years. Its location is extraordinary for many reasons, as it lies, with its entire region, under a spacious and monumental hill, from which plentiful sources spring. The course of these brooks is unbridled and spread out to pass in an abundance of strings by the house of each factory worker. By nature, these lands are not only suitable for cloth making factories, but also for cotton and linen manufactures of any sort." (in: KONARSKI, 1928, p. 185).

It was assumed that the River Jasien would be most suitable for industrial purposes (KOTER, 1969; MARKIEWICZ-KOZAŃSKA, 1995). There were numerous water mills and dams, which could have been easily adapted to power textile machinery. For this very reason, a string of water-front factory settlements was planned in the River Jasien valley, in the place of the former watermill settlements (BACHULSKI, 1931; GINSBERT, 1962; KoTER, 1973; BARANOWSKI, 1980). The first design to take advantage of the Araszt, Wójtowski, Księży and Kulam watermill settlements on the River Jasień was created in 1824. The water-front factory settlements that were marked out in 1824-1827 in the River Jasień valley were to constitute the axis of the magnificent cotton-linen industrial settlement - Łódka (KoTER, 1973; MisSALOWA, 1975; PUŚ, 1987; LISZEWSKI, 2009). The sheer size of this settlement resulted from the technological level of the time, which required the construction of complex water devices - dams, reservoirs, sluices, channels supplying water both for driving purposes, as well as for technological purposes such as: fabric fulling, rinsing, whitewashing, dying. The basic production process, hemp cropping and breaking, as well as spinning, as well as weaving linen and cotton fabrics was to take place in a handicraft colony in a $3 \mathrm{~km}$ long settlement located along Piotrkowska Street (KoTER, 1973; MISSALOWA, 1975; PuŚ, 1987) (Fig. 3).

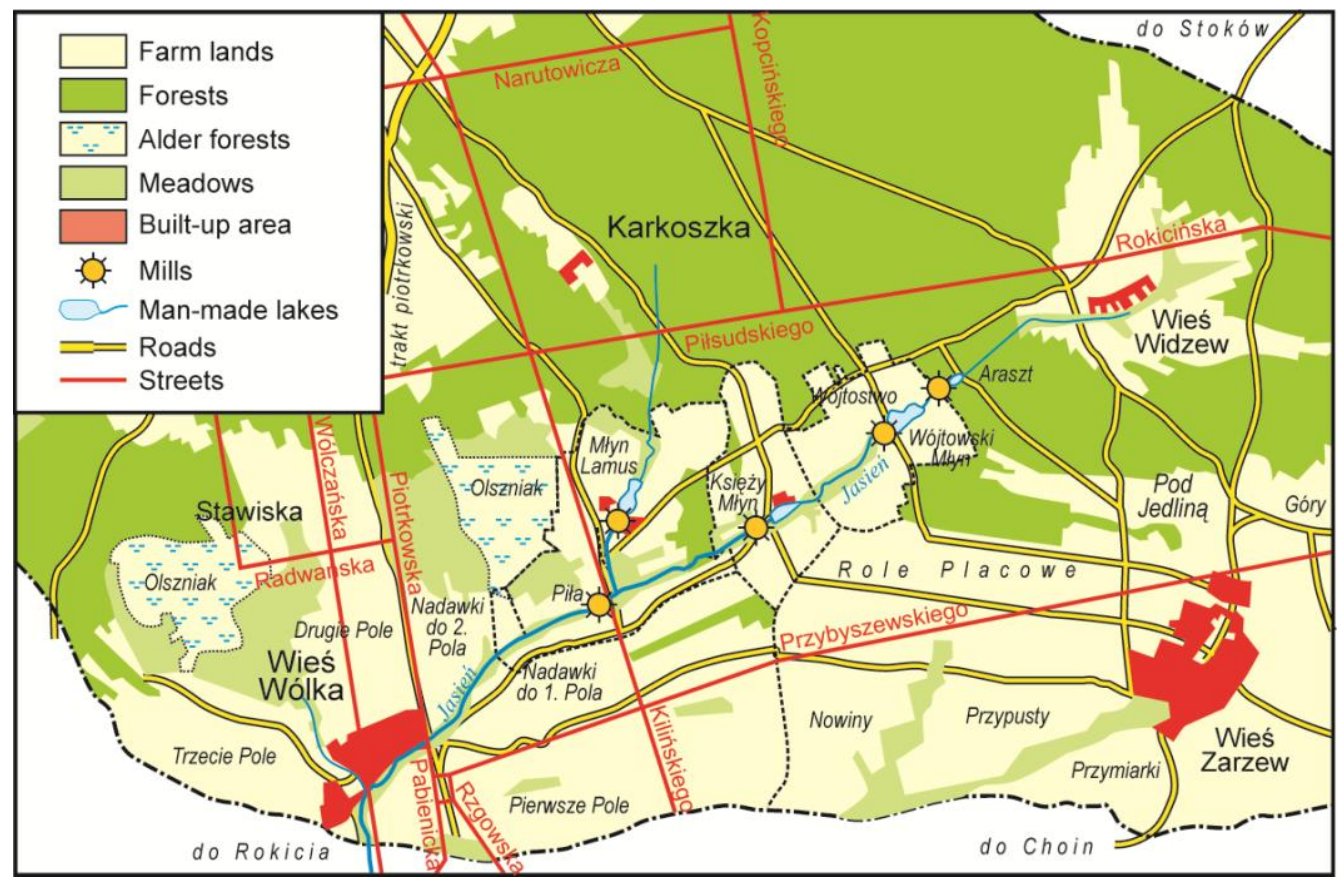

Fig. 3. River Jasień valley at the beginning of the $19^{\text {th }}$ century (source: Szkurłat, 2004) 
The first cotton spinning plant on the River Jasien was opened by Krystian Fryderyk Wendisch, a newcomer from Saxony. In 1824, Rajmund Rembieliński entered into contract with Wendisch for the construction and opening of mechanical linen and cotton spinning factories in the River Jasień valley (BACHULSKI, 1931; POPŁAWSKA, 1972; LISZEWSKI, 2009). A government loan and other benefits were received thanks to the support of Rembieliński and allowed Wendisch to implement significant investments in 1830 by building and opening a spinning mill in 1825 next to Młyn Wójtowski - which utilized the then watermill settlement (Fig. 4); building a cotton purification plant near the Lamus Mill; conducting shore and bed regulation works in the River Jasien; building a spinning mill and in 1827, the large spinning mill building near Księży Młyn.

The new, three-story, brick spinning mill building near Księży Młyn was the tallest building in Łódź at that time (Fig. 5). It was situated several dozen meters from the Jasień riverbed. Its spinning machines had hydraulic drives that utilized the Jasien water drop. A wheel was placed along the longer wall of the building. The drive was distributed by means of a shaft with drums, laid in the centre of the building (POPŁAWSKA, 1973).

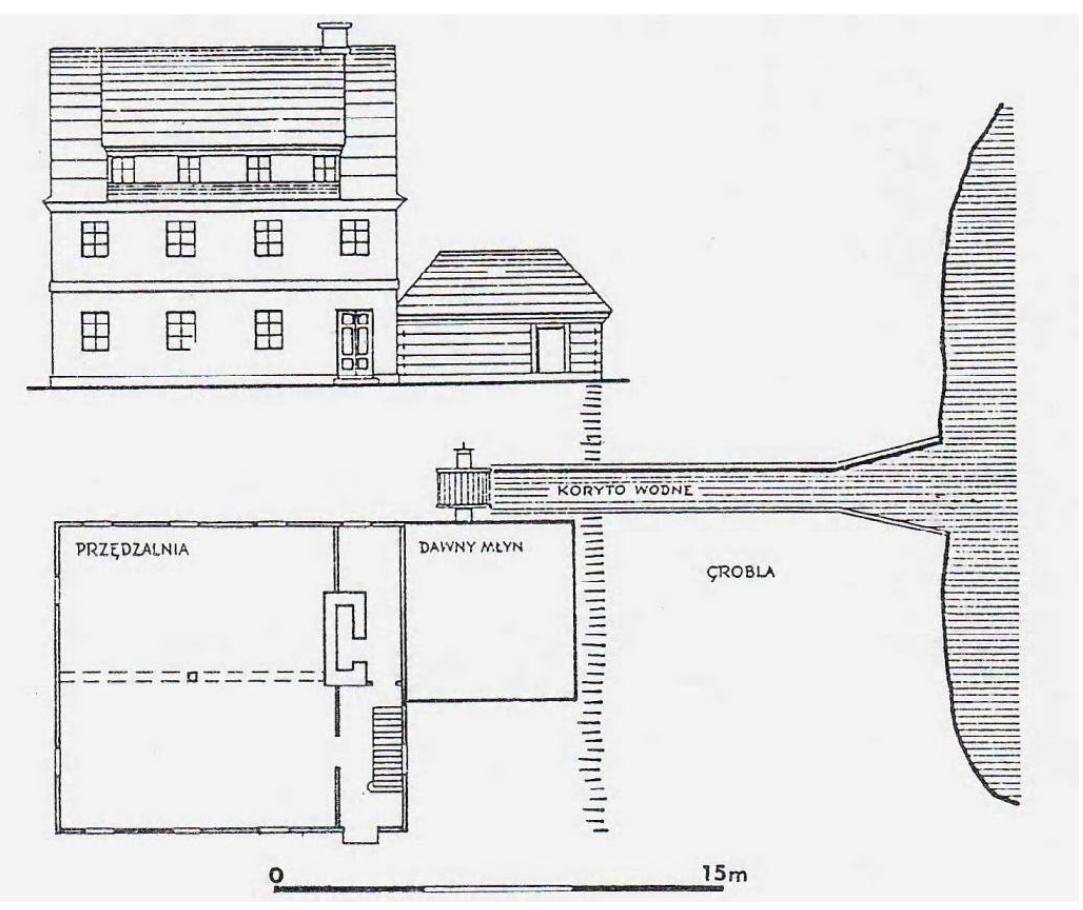

Fig. 4. Wendisch manufacture. Spinning mill built in 1825 in Wójtowski Młyn. Site map copy. AGAD. Collection of maps 30-4. According to I. Popławska (1973)
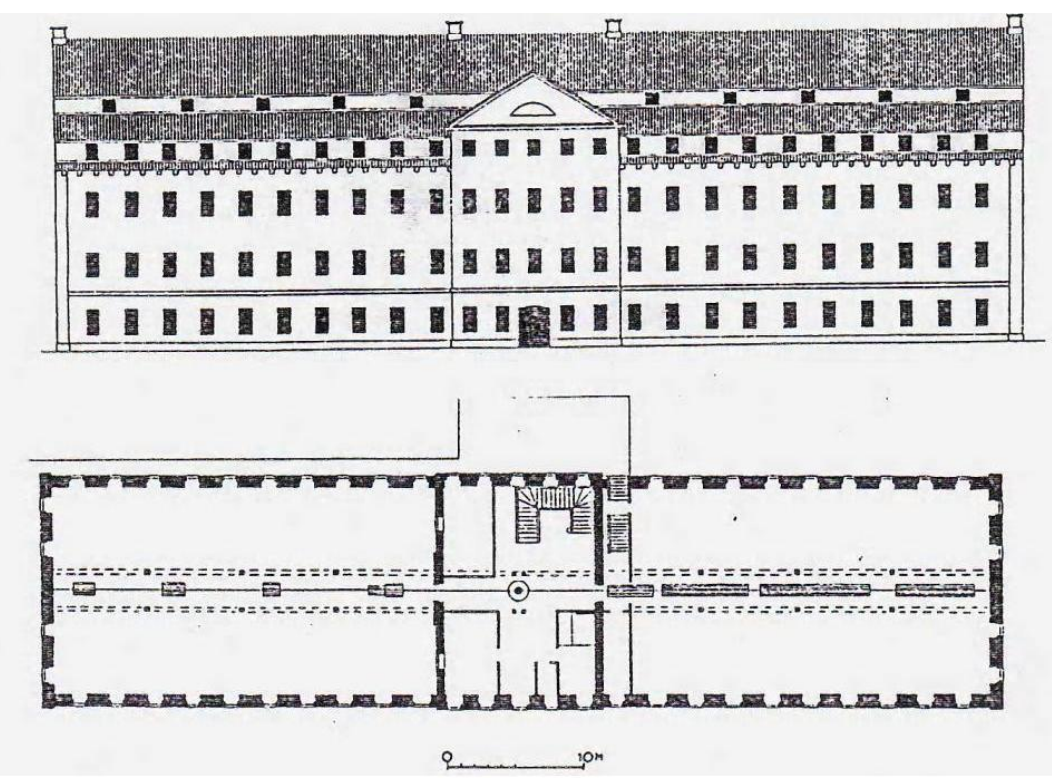

Fig. 5. Wendisch manufacture. Spinning mill in Księży Młyn. Site map copy. AGAD. Collection of maps. 30-4 according to I. Popławska (1973) 
A whitewashing settlement was created below the Wendlisch plant, in the former Kulam mill and Piła sawmill area. Its successive leasee, a wealthy Silesian entrepreneur, Tytus Kopisch, built several buildings there. The grandest of these, the so-called "bielnik" (whitewashing) building is still preserved today, was erected in 1828 at 5 Tymienieckiego Street (KoTER, 1973) (Fig. 6).

The whitewashing plant owned by Kopisch was devoted to finishing linen and cotton fabrics delivered by the handicraft workers. Kopisch was referred to as the father of the linen industry in Łódź. Further down the river, past the Kopisch whitewashing settlement, on the northern side of the newly dammed pond in Piotrkowska Street, there was the A.W. Potempa print house for cotton fabrics and the cotton plant, as well as a magnificent spinning mill - Ludwik Greyer's "White factory". A separate building, erected in the vicinity of the "white factory", was dedicated to house the city's first $60 \mathrm{hp}$ steam engine,

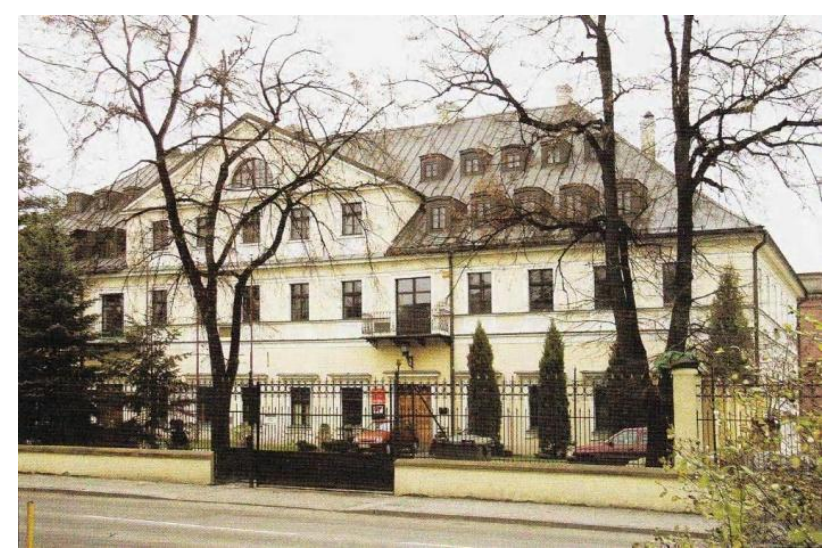

Fig. 6. T. Kopisch whitewashing plant from 1828 at 5 Tymienieckiego Street (A. Kurycki) imported by Geyer in 1839 from the Belgian Cockerill company. Due to the mechanization of the basic production processes, Geyer's plant was the first factory building in Łódź (Fig. 7). The J.T. Lange Turkish red dye plant was built in the lowest area of the factory settlements on the River Jasień. The name of Czerwona Street was named after the plant (LISZEWSKI, 2009).

After L. Geyer used the steam engine to move textile machines for the first time, others started to follow him, applying such drivers in their factories. One of them was the new owner of the spinning mill in Księży Młyn - Karol Moes, who installed a 30hp steam engine. It was installed in an annex of the narrower block of the spinning mill. It is illustrated in the Walkiewicz lithography included in a book about Oskar Flatt of 1853 (Fig. 8) (FLATT, 1853). The factory maintained the original water drive and the sluice with the water wheel. This drive was applied as early as 1860 (КовоJеK, 1998).

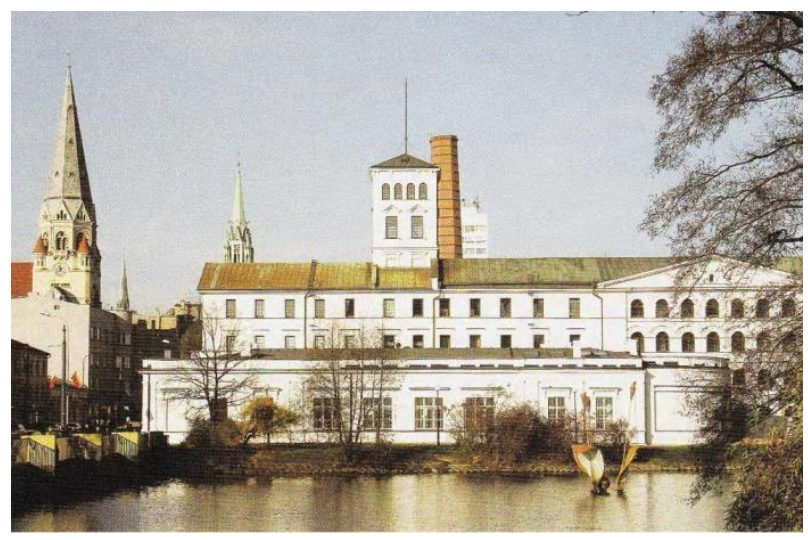

Fig. 7. L. Geyer's White Factory from the 19th century in 282-284 Piotrkowska Street (A. Kurycki)

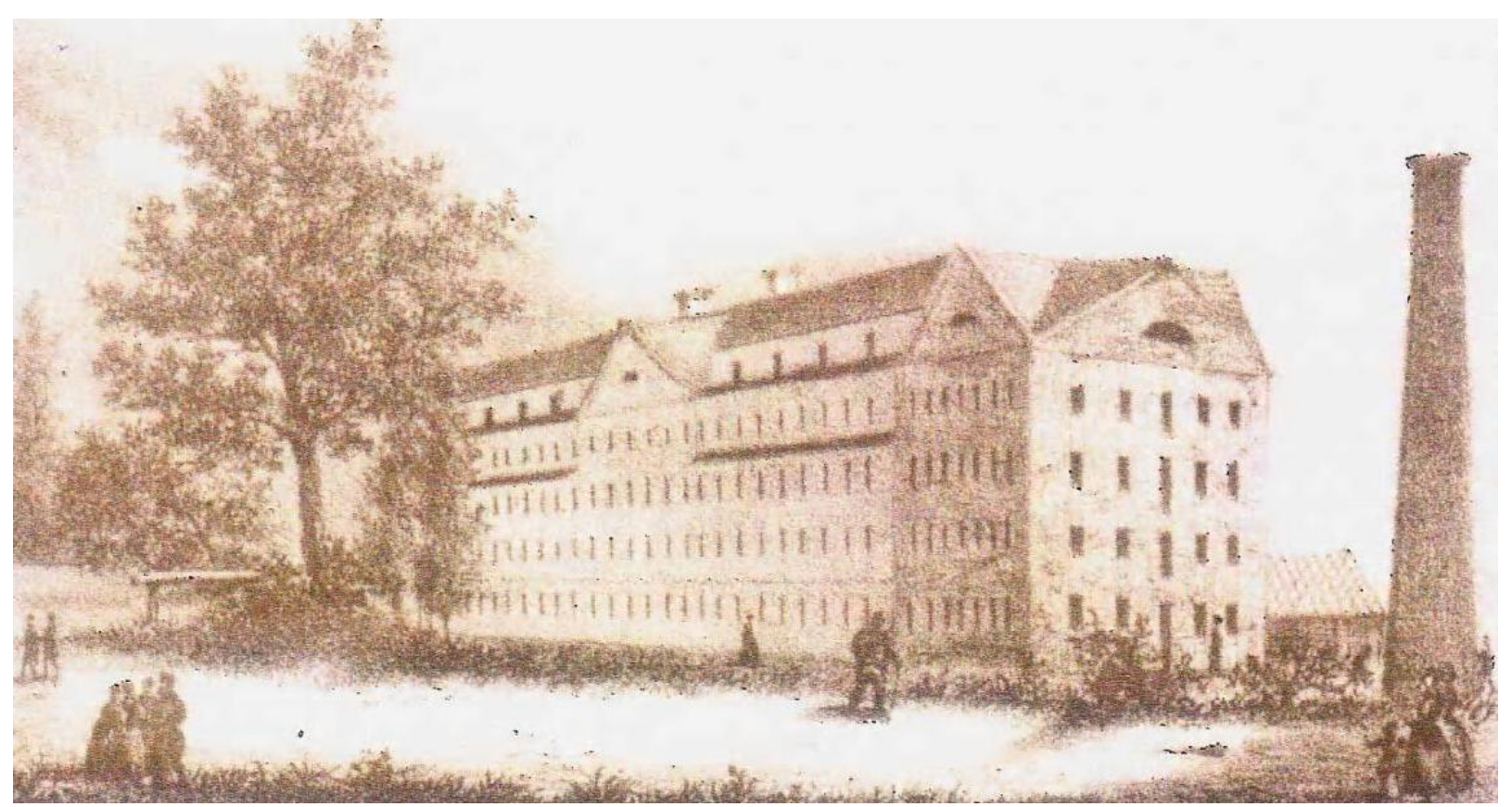

Fig. 8. F.K. Moes factory. W. Walkiewicz lithography (source: Flatt, 1853) 
Between 1870-1878, the Księży Młyn and Wójtowski Młyn estates were purchased by Karol Wilhelm Scheibler, who built a gigantic factory complex located at the junction of Św. Emilia Street (the current K. Tymienieckiego Street) and Przędzalniana Street (the so-called Pfaffendorf). For a very long period, Scheibler's spinning mill building was the largest industrial facility in Łódź. It was $207 \mathrm{~m}$ long and $35.5 \mathrm{~m}$ wide. The building comprised 3 parts, where the central part included a room for the steam engine - the "heart" of the spinning mill. Until then, steam engines had only supported the water drive applied in numerous manufactures and factories and had been placed in so-called annexes (as in the Wendisch manufacture) or in separate buildings (as in the Greyer, Grohmann plant). They came to occupy a central position in the spinning mill, which was indicative of their significance (Ковојек, 1998). It was the steam engine that primarily affected the size and pace of textile production. Its application facilitated further industrial production in the Łódź textile industry. The part of Karol Scheibler's spinning mill, where the steam engine was installed, was given military decorations to emphasize its rank. What is important here is that a spinning mill, in which water energy ceased to matter, could have been located farther away from the river. This became the norm in the mid-19th century. Factory buildings which did not use water energy as the primary drive source, were located further away from the river. This did not, however, mean that the condition of the river water would be improved or that the degrading human interference would cease.

After steam power was introduced as the driving force for textile machines, the role and situation of the River Jasien changed radically. The river lost its importance as the source of mechanical power, as the water intake point for industrial purposes. The abundant inter-moraine waters occurring in the Łódź area provided a water supply for industrial purposes from the level of 10-40 m. Furthermore, it was the first time that water from sub-artesian source levels was extracted and pumped for the purpose of large-area textile production purposes. At the end of the $19^{\text {th }}$ century, water was pumped from several thousand wells and from all aquifers. The volume of water pumped was estimated at over $50000 \mathrm{~m}^{3}$ a day (BIEŻANOWSKI, 2003).

"The water demands were more or less satisfied in the first century of industrial tódź. However, a problem appeared when - literally - an opposite problem was to have been solved. What to do with the used, dirty liquid, polluted with industrial and biological waste was a growing concern. Well, there was the only and the simplest way possible. The used water, along with all of the pollutants, was discharged to the nearest river. Initially, it was drained through ditches, natural watercourses and street gutters. Later on, from larger factories, is would flow through concrete ducts. Thicker waste, particularly feces from sumps, were transported in barrels out of the city center and ... also dumped in the rivers." (BIEŻANOWSKI, 2003, p. 22).

Even earlier than that, in the 1870 s, the local community had started to treat the Jasien riverbed as the place where their wastewaters and faeces were discharged. Successive factory owners, locating their facilities in the vicinity of the riverbed: Kunitzer, Heinzel, Stengert, Silberstein, John and others, also treated the river as a wastewater ditch. Renowned for its abundance, cleanness and high-quality water in the $19^{\text {th }}$ century, the river became a reeking trickle, collecting factory and street sewage in a matter of several dozen years. The factory owners' total disregard for the condition of the water of the River Jasien is proven by the fact that the "King of cotton", Karol Scheibler, did not hesitate to build a factory directly on its riverbed. In the 1890s, Scheibler planned to build a vast production hall of c.a. 3000 ha - the so-called New Spinning Mill, on the western side of Widzewska Street (the current Kilińskiego Street). The River Jasień passed through the middle of the area intended for the spinning mill. Scheibler ordered the designer to leave the river section in its place, cover it with a reinforced floor, to enable the factory to discharge sewage straight into the riverbed (BIEŻANOWSKI, 2003, 2005).

Municipal and factory sewage disposal by discharge to the local rivers was the common practice for decades to come, up until the second half of the $20^{\text {th }}$ century. The absence of a municipal sewage system contributed to the horrible conditions of local rivers. It was only in 1901 that William Lindley was commissioned to design the Łódź water supply and sewage systems. However, the authorities returned to the idea only in 1919. Stefan Skrzywan, an engineer and associate of Lindley, was in charge of the construction. Unfortunately, due to the lack of municipal funds, the construction of municipal sewage commenced as late as 1925 . The system collected a part of the Łódź sewage to the Lublinek wastewater treatment plant, which was opened in 1932. Systematic extension of the sewage system was conducted in Łódź until 1945. Initially, this was the so-called flume sewage, in 
which municipal, industrial wastewater and rainwater were flushed into a single duct. It was found, however, that the main ducts were unable to contain the sewage inflow during major longterm storms. Therefore, in order to maintain the patency of sewage ducts, the so-called overflow sluices were built to release excess sewage to the nearest river. There were 9 such sluices in the River Jasien reservoir. One of the turning points for the cleanness of the water in the Łódź rivers was the construction of separate sewage systems for municipal wastewater and rainwater, initiated in 1955. Thanks to the extension of the sewage system and the construction of the Group Wastewater Treatment Plant, many of the 18 local rivers are no longer typical sewage ducts (BIEŻANOWSKI, 2005).

The current routing of the River Jasien is unclear in numerous sections. Its entire course is contained within the city limits and equals $12.6 \mathrm{~km}$. The current source of the River Jasien is the outlet of the rainwater duct in Giewont Street (Fig. 9).

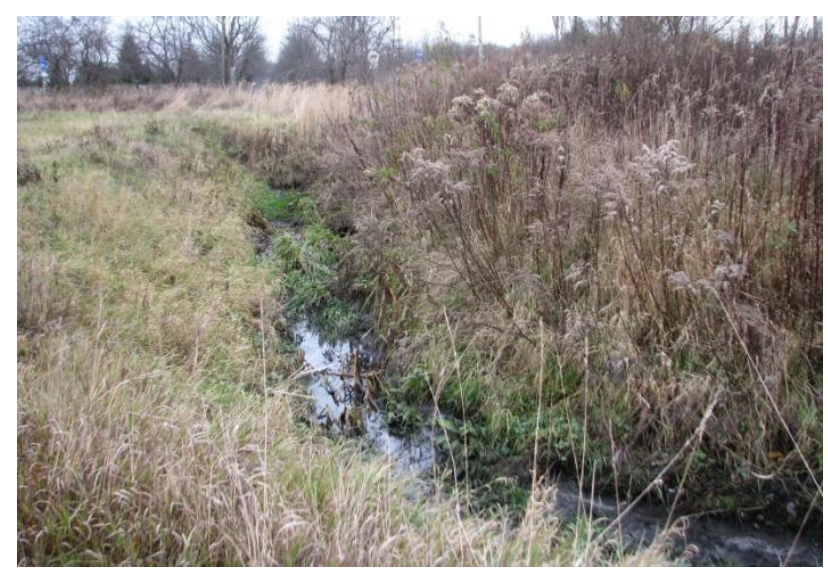

Fig. 9. Initial section of the River Jasień (T. Jarząbek)
In the eastern part - both the valley and the riverbed - were a mild hollow. Further to the west, it is intersected by the North-South communication route - Rydza-Śmigłego Street. Farther to the west, in the vicinity of Przędzalniana Street, adjacent to the vast Scheibler industrial complex, the River Jasien forms a large flood reservoir. On the western side of Przędzalniana Street, only a small section of the river is uncovered and visible as a concrete ditch isolated from its natural ground water supply. Father on, the River Jasien flows in a covered reservoir up to Piękna Street (Fig. 10). From Piękna Street to the Ner outlet, the River Jasień flows in an open, reinforced riverbed (Fig. 11).

At the beginning of the $20^{\text {th }}$ century, the depth of the River Jasien was more than $1 \mathrm{~m}$ in the vicinity of Księży Młyn (KonARSKi, 1928). It is currently carrying small amounts of drainage water and unidentified municipal-industrial waste. Larger volumes of water collect in the river only during high rainfall.

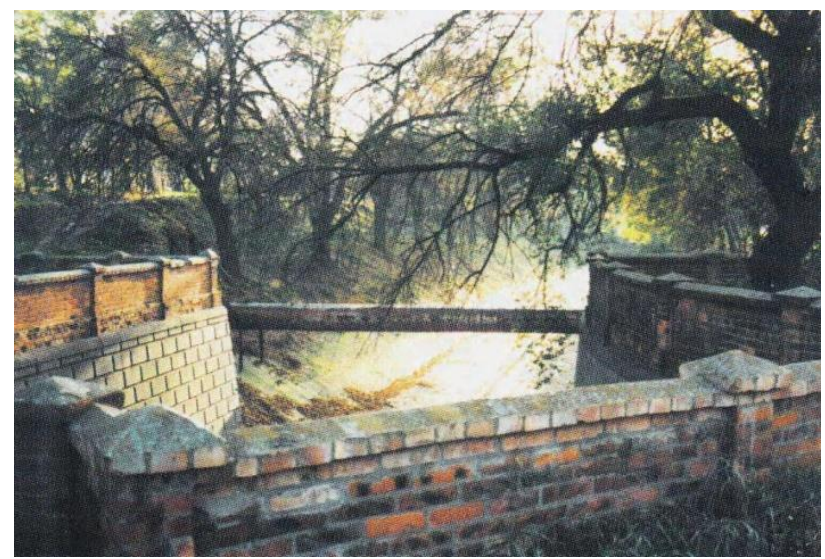

Fig. 10. River Jasień in the concrete channel - central river section (B. Sierecka-Nowakowska)

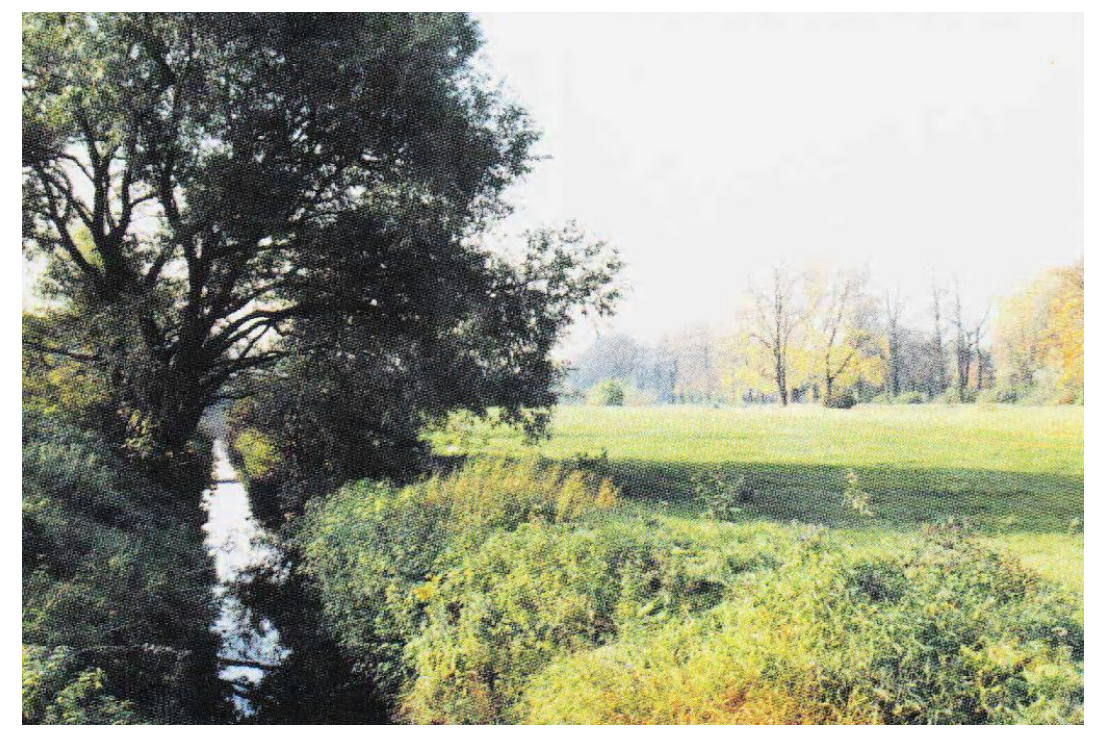

Fig. 11. River Jasień in open areas in the western - estuarine section (B. Sierecka-Nowakowska) 


\section{Conclusion}

The history of the River Jasień illustrates how people who had lived in harmony with nature for ages, destroyed its natural beauty, leading to its degradation during the period of rapid industrial development. Considering the River Jasień as an example of, we can observe how man - river relations changed during the course of technological development of the textile industry:

\section{Stages of economic development of the Jasien} riverbed

1. Forest - agricultural use

2. Agricultural use - water mills

3. Textile production - manufacture

4. Textile production - factory, applying a steam engine

5. Industrial textile production - water collected primarily from deep wells

6. Fall of the textile industry

\section{Types of man - river relations}

1. Period of primary balance of the man-river function, subjects human activity to the natural rhythm of the river

2. Dominant use of energy produced by the river water fall

3. Use of the river for energy purposes is still the dominant use

4. Water loses its significance as an energy source - used mainly for rinsing, whitewashing, dying fabrics

5. The riverbed becomes the main sewage discharge channel

6. The process of "abandonment" the river proceeds - the river loses its significance (apart from collecting rainwater) as the source of water, as well as for the landscape
The Łódź river valleys, similar to other cities, which had once "turned their backs to the river", should become an important element of the city's spatial policy (PANCEWICZ, 2002). The situation presented illustrates that, particularly in postindustrial areas, there is a need to renew the man-river relations by restoring and conserving the natural, cultural and civilization heritage. When planning the development of the River Jasień, it is necessary to create a more harmonious landscape, one that is more human-friendly, environment-friendly and culture-friendly. Not only in the River Jasień valley, but also with other Łódź rivers, there is a need to revitalize and restore the riverbank spaces to recreate their natural value, at least in part. What is important is that we strive to maintain the unique character of the place, by improving the accessibility of riverside areas, and using the river valley and riverbed to shape the identity of the place.

\section{References}

Angiel J. 2011. Rzeka Wisła, jej wartości i percepcja. Wisła w edukacji geograficznej. WGiSR UW, Warszawa.

Bachulski A. 1931. Pierwsza przędzalnia bawełny w Łodzi Christiana Fryderyka Wendischa. Rocz. Łódzki, II.

Baranowski B., Fijałek J., Rosin R. (eds.) 1980. Łódź. Dzieje miasta. T.1, Do 1988 r., Warszawa- Łódź.

Berbelska D., Pytlas S., Salm J., Zielińska A. 1998. Księży Młyn, Urząd Miasta Łodzi, Wydział Strategii Miasta.
Bieżanowski W. 2003. Łódka i inne rzeki łódzkie. Widzewska Oficyna Wyd. ZORA, Łódź.

Bieżanowski W. 2005. Z dziejów kanalizacji i wodociągów łódzkich. Widzewska Oficyna Wyd. ZORA, Łódź.

Dylik J. 1971. Województwo ze stolicą bez antenatów. Geografia historyczna ziem województwa łódzkiego. Łódz. Tow. Nauk., Łódź.

Ginsbert A. 1962. Łódź, Studium monograficzne. Wyd. Łódzkie, Łódź.

Flatt 0. 1853. Opis miasta Łodzi pod względem historycznym, statystycznym i przemysłowym, Warszawa.

Jaskulski M. 1995. Stare fabryki Łodzi. Widzewska Oficyna Wyd. ZORA, Łódź.

Kobojek G. 1998. Księży Młyn. Widzewska Oficyna Wyd. ZORA, Łódź.

Konarski K. 1928. Stanisław Staszic w Łodzi w roku 1825. Rocz. Łódzki, 1: 179-189.

Koter M. 1969. Geneza układu przestrzennego Łodzi przemysłowej. Prace IG PAN, 79, Warszawa.

Koter M. 1973. Szlakiem historycznego rozwoju Łodzi. Łódź.

Koter M. 1974. Środowisko przyrodnicze obszaru obecnej Łodzi jako podłoże rozwoju osadnictwa $w$ okresie przedprzemysłowym. Rada nauk. przy Prezydencie M. Łodzi, Łódź.

Markiewicz-Kozańska E. 1995. Przemiany urbanistyczne $w$ przedsiębiorstwie I.K. Poznańskiego $w$ Łodzi w II połowie XIX wieku. Urbanistyka. Międzyuczeln. Zesz. Nauk., 1, Warszawa.

Missalowa, G. 1975. Studia nad powstaniem Łódzkiego Okręgu Przemysłowego 1815-1870. T. 1: Przemysł. Łódź.

Liszewski S. 2009. Łódź. Monografia miasta. Łódz. Tow. Nauk., Łódź.

Olaczek R. 2002. Rzeka w życiu lokalnej społeczności. [in:] Kołtuniak J. (ed.) Rzeki. Kultura. Cywilizacja. t. 11, Wyd. Śląsk, Katowice: 183-211. 
Ostrowski W. 1949. Świetna karta z dziejów planowania $w$ Polsce 1815-1830. Tow. Urban. Pol., Warszawa.

Pancewicz A. 2002. Rzeka w przestrzeni miejskiej. Próba określenia wzajemnych relacji. [in:] Kołtuniak J. (ed.) Rzeki. Kultura. Cywilizacja. t. 11, Wyd. Śląsk, Katowice: 256-270.

Popławska I. 1972. Zespół fabryczno - rezydencjonalny Księży Młyn w Łodzi. Kwart. Arch. Urban. PAN, 29, 4.

Popławska I. 1973. Architektura przemysłowej Łodzi w XIX w. Stud. i mat. do teorii i historii arch. i urban., 11, Warszawa.

Popławska I. 1974. Dawne fabryki Łodzi. Biuro Badań i Dokum. Zabytków, Łódź.

Puś W. 1976. Przemysł włókienniczy w Królestwie Polskim w latach 1870-1900. Zesz. Nauk. Uniw. Łódz., ser. I, Uniw. Łódz., Łódź.

Puś W., Pytlas S. 1979. Dzieje Łódzkich Zakładów Przemysłu Bawełnianego im. Obrońców Pokoju „Uniontex” w latach 1827-1977. Warszawa - Łódź.

Puś W. 1987. Dzieje Łodzi przemysłowej (zarys historii). Muz. Hist. Miasta, Centrum Inf. Kult., Łódź.
Rynkowska A. 1951. Działalność gospodarcza Królestwa Polskiego na terenie Łodzi przemysłowej $w$ latach 1821-1831. T. 5, Prace Wydziału 2. Nauk Hist. i Społ., Łódz. Tow. Nauk., Łódź. Sierecka-Nowakowska B. 1999. Rozwój przestrzenny Łodzi przemysłowej u progu XXI wieku w oparciu o dziedzictwo przyrodniczo-kulturowe. Monografie. Polit. Łódzka, Łódź.

Stefański K. 2001. Jak zbudowano przemysłowa Łódź. Architektura i urbanistyka miasta w latach 1821-1914. Łódź.

Szkurłat E. 1992. Poznaj swoje miasto. Mat. krajoznawcze. Region. Prac. Krajoz. PTTK, Łódź.

Szkurłat E. (ed.) 2004. Moja mała ojczyzna - Łódź i region Polski Środkowej. Łódz. Tow. Nauk., Łódź.

Wierzbicka B. (ed.) 1996. Miasto tyłem do rzeki, Bibl. Tow. Opieki nad Zabytkami. Warszawa.

Wojciechowski K.H. 2000. Człowiek i rzeka w układzie przyrodniczym i gospodarczym. [in:] Kołtuniak J. (ed.) Rzeki. Kultura. Cywilizacja. t. 9, Wyd. Śląsk, Katowice: 187-198. 